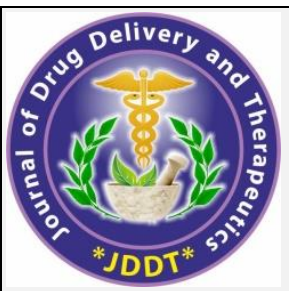

Open $\odot$ Access
Available online on 15.12.2020 at http://jddtonline.info

\section{Journal of Drug Delivery and Therapeutics}

Open Access to Pharmaceutical and Medical Research

(C) 2011-18, publisher and licensee JDDT, This is an Open Access article which permits unrestricted non-commercial use(CC By-NC), provided the original work is properly cited

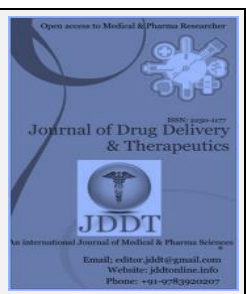

Research Article

\title{
Clinicopathological Profile of Low-Grade B Cell Non-Hodgkin Lymphoma in Tertiary Health Care in West Java Indonesia
}

\author{
Primastari Etis*, Hernowo Bethy Suryawathy, Dewayani Birgitta Maria \\ Anatomical Pathology Department, Medicine Faculty, Padjadjaran University/ Hasan Sadikin General Hospital, Bandung, Indonesia
}

\begin{abstract}
Background: Low-grade B cell Non-Hodgkin lymphomas (NHL) are a group of lymphomas that are predominantly indolent and make up approximately $50 \%$ of all malignant lymphomas. Initial therapy for low-grade B cell LNH has an overall response rate of between $85-94 \%$ and a refractory rate of $6-10 \%$. Few reports have been published regarding the clinicopathological characteristics of non-Hodgkin lymphoma cases, especially low-grade B cell types. This research aims to determine the clinicopathological profile of low-grade B cell type non-Hodgkin lymphoma cases.
\end{abstract}

Method: This research is a descriptive study using cross-sectional methods. The sample consisted of 40 low-grade B cell type NHL cases from January 2015 to June 2020 at Hasan Sadikin Hospital, Bandung. Clinicopathological data, including age, sex, location of the tumor (nodal or extranodal), stage, B symptoms, and response to therapy, were taken from the patients' medical records. Data were categorized into 2 groups based on response to initial therapy.

Results and Discussion: Of the 40 cases diagnosed with low-grade B cell type NHL, 55\% responded to initial therapy. From the non-response group, $61.1 \%$ were stage II and $72.2 \%$ exhibited B symptoms. There were no significant differences in age, sex, tumor location (nodal or extranodal), stage, or B symptoms in the response and non-response groups.

Conclusion: In this study, $45 \%$ of patients with low-grade B cell type NHL did not respond to initial therapy. There was no statistically significant difference in the clinicopathological profiles of the response and non-response groups to initial therapy in cases of low-grade B cell type NHL.

Keywords: Non-Hodgkin Lymphoma, low-grade B cell lymphoma, therapy response, clinicopathological

Article Info: Received 12 Oct 2020; $\quad$ Review Completed 26 Nov 2020; $\quad$ Accepted 04 Dec 2020; Available online 15 Dec 2020

Cite this article as: Primastari E, Hernowo BS, Dewayani BM, Clinicopathological Profile of Low-Grade B Cell NonHodgkin Lymphoma in Tertiary Health Care in West Java Indonesia, Journal of Drug Delivery and Therapeutics. 2020; 10(6s):89-91 http://dx.doi.org/10.22270/jddt.v10i6-s.4632

*Address for Correspondence: Primastari Etis, Anatomical Pathology Department, Medicine Faculty, Padjadjaran University/ Hasan Sadikin General Hospital, Bandung, Indonesia

\section{INTRODUCTION}

Low-grade B cell non-Hodgkin lymphomas (NHL) are a group of lymphoma subtypes that are predominantly indolent. ${ }^{1}$ According to data from GLOBOCAN and Cancer Incidence in Five Continents (CI5), LNH is ranked $5^{\text {th }}$ to $9^{\text {th }}$ most malignant in countries around the world, with the number of new cases reaching nearly 510,000, and a mortality rate of 14,164 cases in $2018 .^{2,3}$ In Indonesia there were 14,164 new cases and 7,565 deaths in 2018.4 In general, low-grade NHL represent $50 \%$ of malignant lymphomas. ${ }^{5}$

The etiology and pathogenesis of low-grade $B$ cell nonHodgkin lymphoma are associated with Deoxyribonucleic acid (DNA) changes, including gene mutations, amplification, deletions, or chromosomal translocations. The patient's clinical symptoms are usually a painless mass (nodal or extranodal) that enlarges slowly. Occasionally organomegaly, including hepatomegaly and spenomegali, are found, and occassionally there are non-specific symptoms.6-10
Histopathologic and immunohistochemistry (IHC) examinations of CD20, CD3, and Ki67 are used to diagnose low-grade B cell type non-Hodgkin lymphoma. To determine the subtype, further IHC examinations can be conducted for each subtype. The therapeutic modalities used in NHL are chemotherapy, radiotherapy, targeted therapy, and immunotherapy. The therapy used is chosen based on the lymphoma subtype, grading, and staging. ${ }^{11}$ The prognosis is generally influenced by the patient's age, clinical signs and symptoms, low-grade B cell NHL subtype, grading, and staging. The majority of low-grade NHL are indolent but generally incurable. In the initial stages of therapy, low-grade NHL are extremely responsive, followed by a relapseremitting phase with increased resistance to therapy and a shortened response duration. 12

Articles and data on the clinicopathological characteristics of low-grade $B$ cell non-Hodgkin lymphoma patients in Indonesia are extremely limited. The aim of this research is to provide information on low-grade $\mathrm{B}$ cell non-Hodgkin 
lymphoma cases in Dr. Hasan Sadikin Central General Hospital in Bandung, West Java, Indonesia.

\section{MATERIAL AND METHOD}

This research is an observational study using cross-sectional methods, examining 40 cases of low-grade B cell type nonHodgkin lymphoma from January 2015 to June 2020. The research subjects' clinical data were obtained from their medical records, including age, sex, tumor location (nodal or extranodal), stage, B symptoms, and response to therapy. Data on subtype were obtained from histopathological and immunohistochemical examinations by the Dr. Hasan Sadikin Central General Hospital Anatomic Pathology Department. Data were analyzed using IBM SPSS statistics 26.

\section{RESULTS}

The research results highlight demographic data and clinical features as characteristics of the research subjects. Demographic data were taken from 40 research subjects in the age range of 27-77 years, with a mean age of 53.48 and a median age of 55 years. There were a greater number of male than female subjects.

The clinical features of the subjects showed that $72.5 \%$ had B symptoms and that the primary tumor was extranodal in $75 \%$ of cases. Clinical stages were mostly stage II, with the smallest number being stage IV. In this study, more cases were in the initial stages (stage I and II) than advanced stages (stage III and IV). Twenty-two of the research subjects responded well (responded) to R-CHOP immunochemotherapy, while 24 cases were non-responsive.

Cases that were declared as 'responsive' to therapy incuded those that showed a 'complete response' and 'partial response', while cases with a 'stable disease' and 'progression disease' response were placed in the nonresponse group. In Table 1, the analysis of the numerical age variable was tested using the unpaired T test. Analyses of the variables of sex, location of the primary tumor, and $B$ symptoms were tested using the chi-square statistical test. Analyses of the Ann Arbor stage and subtype variables were conducted using the Kolmogorov-Smirnov test. The analysis of characteristic variables in Table 1 shows a p-value greater than 0.05 , indicating no significant corelation between the characteristic variables of the research subjects and therapeutic response ( $p$-value $>0.05$ ). Based on the test results, it can be concluded that the two groups (response and non-response groups) are the same. In Table 1 , it can be seen that cases that did not respond to this study predominantly were male, exhibited B symptoms, in the early clinical stages, and in the marginal zone lymphoma (MZL) subtype, with primay extranodal location of the tumor.

Table 1. Data Comparison between Characteristics of Study Subjects by chemotherapy response group

\begin{tabular}{|c|c|c|c|}
\hline \multirow[b]{2}{*}{ Variable } & \multicolumn{2}{|c|}{ Therapy response } & \multirow[b]{2}{*}{$P$ value } \\
\hline & $\begin{array}{c}\text { Response } \\
\mathrm{N}=22\end{array}$ & $\begin{array}{c}\text { Non Response } \\
\mathrm{N}=18\end{array}$ & \\
\hline Age (years old) & & & 0.926 \\
\hline Mean \pm Std & $53.32 \pm 10.580$ & $53.67 \pm 12.939$ & \\
\hline Median & 54.50 & 56.50 & \\
\hline Range (min-max) & $37.00-73.00$ & $27.00-77.00$ & \\
\hline Gender & & & 0.071 \\
\hline Male & $18(81.8 \%)$ & $10(55.6 \%)$ & \\
\hline Female & $4(18.2 \%)$ & $8(44.4 \%)$ & \\
\hline Location & & & 0.067 \\
\hline Nodal & $8(36.4 \%)$ & $2(11.1 \%)$ & \\
\hline Extranodal & $14(63.6 \%)$ & $16(88.9 \%)$ & \\
\hline Stage & & & 0.659 \\
\hline I & $2(9.1 \%)$ & $3(16.7 \%)$ & \\
\hline II & $10(45.5 \%$ & $11(61.1 \%)$ & \\
\hline III & $10(45.5 \%)$ & $3(16.7 \%)$ & \\
\hline IV & $0(0.0 \%)$ & $1(5.6 \%)$ & \\
\hline B symptoms & & & 0.972 \\
\hline Yes & $16(72.7 \%)$ & $13(72.2 \%)$ & \\
\hline No & $6(27.3 \%)$ & $5(27.8 \%)$ & \\
\hline Subtype & & & 0.632 \\
\hline Small lymphocytic lymphoma (SLL) & $8(36.4 \%)$ & $6(33.3 \%)$ & \\
\hline Mantle cell lymphoma (MCL) & $1(4.5 \%)$ & $0(0.0 \%)$ & \\
\hline Follicular lymphoma (FL) & $6(27.3 \%)$ & $2(11.1 \%)$ & \\
\hline Marginal zone lymphoma (MZL) & $7(31.8 \%)$ & $10(55.6 \%)$ & \\
\hline
\end{tabular}

\section{DISCUSSION}

In terms of the characteristic of age, data for each of the study's therapeutical response groups were normally distributed, with a similar mean age, indicating that age was not a confounding factor for the study. In the study, cases of low-grade B cell type NHL were obtained from patients between the ages of 27 - 77 years, with a mean age of 53 years and a median age of 55 years. The median value is slightly different to the median age of 59 years for low-grade B cell type NHL in countries from the 'far east' category in Perry et al.'s study. ${ }^{13}$ In comparison, the median age for lowgrade B cell type NHL in developed countries (North America and West Europe) is higher, at 63 years. ${ }^{13}$ The difference may 
be influenced by differences in population and research sample size.

In this study, data on gender indicated a higher number of males than females (7:3), although statistically insignificant. This finding is similar to the WHO epidemiology and research conducted by Perry et al. ${ }^{13}$ which showed a greater number of cases among men than women in both developed and developing countries.

The majority of cases in this study were classed as stage II, at $52.5 \%$, followed by stage I at $12.5 \%$, stage III at $32.5 \%$ and stage IV at $2.5 \%$. A retrospective study by Ciobanu et al. ${ }^{14}$ produced different results, with $83.3 \%$ of cases being stage III-IV. This is possibly due to the majority of cases included in the study exhibiting B symptoms, despite being detected in the early stages. In stage I, up to $20 \%(1 / 5)$ of cases were accompanied by B symptoms, $90.5 \%(18 / 21)$ in stage II, $61.5 \%(8 / 13)$ in stage III, and $100 \%(1 / 1)$ in stage IV. It is possible that many of the cases were detected in the early stages due to the emergence of B symptoms, leading the patients to seek healthcare services. If viewed by subtype, 10/14 SLL cases (71.4\%) exhibited B symptoms, in contrast to research conducted by Mukkamalla SKR et al.15 which found that only $5-10 \%$ of patients with SLL experienced B symptoms. This finding was the same for Marginal Zone Lymphoma (MZL), with 58.8\% (10/17) of cases in the study exhibiting B symptoms. According to the WHO, approximately $10-20 \%$ of MZL experience B symptoms. All cases (9/9) of follicular lymphoma in this study experienced B symptoms. Meanwhile, according to the WHO, B symptoms rarely occur in MZL. B symptoms are associated with an increase in inflammatory proteins in the plasma that are related to poorer response to chemotherapy and survival rate than patients with normal inflammatory proteins in the plasma. ${ }^{16}$ In this study, B symptoms had no significant relationship with immunochemotherapy response to RCHOP.

The cases used as subjects in this research were all immunohistochemically diagnosed as B cell type NHL (CD20 positive, CD3 negative) and had a Ki67 proliferation index of below 30\% (low grade). Some of the most common B cell type NHL subtypes are follicular lymphoma (FL), marginal zone lymphoma (MZL), chronic lymphocytic leukemia/small lymphocytic lymphoma (CLL/SLL), and mantle cell lymphoma (MCL). In this research, the majority of cases fell under the MZL subtype (42.5\%), followed by SLL (35\%), FL $(22.5 \%)$ and MCL (2.5\%). This finding deviates from the results of a study conducted by Perry et al.13, which found that from the low-grade B cell type NHL group, FL was the largest subtype, followed by MZL (MALT and Nodal), MCL and lastly SLL/CLL. This difference may be due to differences in population and sample size. For example, the study conducted by Perry et al. found differences in subtype percentage between asia and western countries, including that there were significantly more cases of MZL and fewer FL and MCL in asia countries

According to data on responses to R-CHOP immunochemotherapy from this study, $55 \%$ of cases responded to R-CHOP immunochemotherapy. In a study by Walewski et al. ${ }^{17}$, indolent lymphoma therapy using R-CHOP had an overall response rate (complete and partial response) of $94.5 \%$. This difference in findings may be due to differences in the characteristics of the low-grade B cell type NHL populations.
Acknowledgment: We thank the Anatomical Pathology Department Padjdjaran University and Medical Record Department Hasan Sadikin central general hospital Bandung for helping us to do this research.

\section{Conflict of Interest: The authors declare no conflict of} interest.

\section{REFERENCES}

1. Quintanilla-Martinez L. The 2016 updated WHO classification of lymphoid neoplasias. Hematological Oncology. 2017; 35(S1):3745.

2. Piñeros M, ZNaor A, Marcos-Gragera R, Steliarova-Foucher E. Global patterns and trends in the incidence of non-Hodgkin lymphoma. Cancer causes \& control. 2019 May; 30(5):489-99.

3. Bray F, Ferlay J, Soerjomataram I, Siegel RL, Torre LA, Jemal A. Global cancer statistics 2018: GLOBOCAN estimates of incidence and mortality worldwide for 36 cancers in 185 countries. CA: A Cancer Journal for Clinicians. 2018 Nov 1; 68(6):394-424.

4. The Global Cancer Observatory. Indonesia Population Fact Sheet [Internet]. IARC WHO; 2018. Available from: https://gco.iarc.fr/today/data/factsheets/populations/360indonesia-fact-sheets.pdf

5. Cömert P, Yıldız A, Yıldırım M, Afacan Öztürk HB, Pala Ç, Albayrak $M$, et al. Prognostic Factors in Patients with Low-Grade Nonhodgkin Lymphoma. Indian Journal of Hematology and Blood Transfusion. 2019 Aug 6; Available from: https://doi.org/10.1007/s12288-019-01168-9

6. Freedman A. Follicular lymphoma: 2018 update on diagnosis and management. American Journal of Hematology. 2018 Feb 1;93(2):296-305.

7. Jain P, Wang M. Mantle cell lymphoma: 2019 update on the diagnosis, pathogenesis, prognostication, and management. American Journal of Hematology. 2019 Jun 1; 94(6):710-25.

8. Bron D, Meuleman N. Marginal zone lymphomas: second most common lymphomas in older patients. Current opinion in oncology. 2019; 31(5):386-93.

9. Kang J, Hong JY, Suh C. Clinical features and survival outcomes of patients with lymphoplasmacytic lymphoma, including non-IgM type, in Korea: a single-center experience. Blood Res. 2018 Sep; 53(3):18997.

10. Zelenetz AD, Gordon LI, Wierda WG, Abramson JS, Advani RH, Andreadis CB, et al. Chronic lymphocytic leukemia/small lymphocytic lymphoma, version 1.2015. J Natl Compr Canc Netw. 2015 Mar; 13(3):326-62.

11. Zelenetz AD, Gordon LI, Abramson JS, Advani RH, Bartlett NL, Caimi PF, et al. NCCN Guidelines Version 4.2019 B cell Lymphoma. National Comprehensive Cancer Network; 2019. Available from: www.nccn.org

12. Ninkovic S, Lambert J. Non-Hodgkin lymphoma. Medicine. 2017 May; 45(5):297-304.

13. Perry AM, Diebold J, Nathwani BN, MacLennan KA, MüllerHermelink HK, Bast $M$, et al. Non-Hodgkin lymphoma in the developing world: review of 4539 cases from the International Non-Hodgkin Lymphoma Classification Project. Haematologica. 2016/06/27 ed. 2016 0ct; 101(10):1244-50.

14. Ciobanu A, Stanca O, Triantafyllidis I, Lupu A. Indolent lymphoma: diagnosis and prognosis in medical practice. Maedica (Bucur). 2013 Sep; 8(4):338-42.

15. Mukkamalla S, Taneja A, Malipeddi D. Chronic Lymphocytic Leukemia. In: StatPearls Publishing; 2020. Available from: https://www.ncbi.nlm.nih.gov/books/NBK470433/

16. Sharma R, Cunningham D, Smith P, Robertson G, Dent O, Clarke SJ. Inflammatory (B) symptoms are independent predictors of myelosuppression from chemotherapy in Non-Hodgkin Lymphoma (NHL) patients--analysis of data from a British National Lymphoma Investigation phase III trial comparing CHOP to PMitCEBO. BMC Cancer. 2009 May 18; 9:153-153.

17. Walewski J, Paszkiewicz-Kozik E, Michalski W, Rymkiewicz G, Szpila T, Butrym A, et al. First-line R-CVP versus R-CHOP induction immunochemotherapy for indolent lymphoma with rituximab maintenance. A multicentre, phase III randomized study by the Polish Lymphoma Research Group PLRG4. British Journal of Haematology [Internet]. 2019 Dec 2. Available from: https://doi.org/10.1111/bjh.16264 